\title{
The Role of Organic Matter in Soil Acidification
}

\author{
G. S. P. Ritchie and P. J. Dolling
}

\begin{abstract}
The $\mathrm{pH}$ and buffer capacity of two soils increased or remained constant after incubation with different amounts of plant material (lucerne chaff) at field capacity and when air dry. For both soils, the pH changes were greater at field capacity, whereas the buffer capacities were independent of the water treatments.

The $\mathrm{pH}$ changes observed could be explained in terms of the organic anion concentration of the plant material. The results indicate that the initial soil $\mathrm{pH}$ and the anion concentration (i.e. the per cent dissociation of soluble organic acids when released into the soil) determine the acidifying effect of organic matter.
\end{abstract}

\section{Introduction}

Continuing soil acidification under clover pastures has beet observed in several parts of Australia (Williams and Donald 1957; Russell 1960; Williams 1980) and has been attributed to the accumulation of organic matter in the soils. However, the accumulation of organic matter is not the only mechanism that can lead to soil acidification in cultivated soils. The process of nitrogen cycling in an open system (Helyar 1976), and the removal of greater amounts of inorganic cations than anions in plant products (Riley and Barber 1969), have also been identified as potentially important factors in the development of acid soils.

Williams (1980) pointed out that the decrease in soil $\mathrm{pH}$ with years of pasture production occurred at depths $>30 \mathrm{~cm}$, whereas organic matter accumulation only occurred in the top $10 \mathrm{~cm}$ of the soil. Jarvis and Robson (1983) have observed a $\mathrm{pH}$ increase in a soil that had been used for pasture production for over 20 years, even though the organic matter content of the cultivated soil was more than double that of the virgin soil.

There are two possible explanations for these conflicting observations. Either organic matter accumulation does not necessarily result in $\mathrm{pH}$ decreases or other mechanisms causing $\mathrm{pH}$ change are more dominant. It would appear that the role of organic matter in soil acidification is not fully understood and merits further investigation.

There have been no systematic studies of the effect of the addition of plant material on soil $\mathrm{pH}$ under natural conditions. Indeed, most work with organic matter has used purified material previously extracted by strong acids or alkali. Also, no clear distinction has been made between the roles played by soluble and insoluble components of the breakdown products in their natural state. 
Consequently, the work reported here was initiated to investigate some properties of lucerne chaff and the effect of its addition on soil $\mathrm{pH}$.

\section{Materials and Methods}

\section{Soils}

The soils used in the study were selected on the basis of their low organic matter content and different $\mathrm{pH}$ values. Soil samples were collected from the $0-10 \mathrm{~cm}$ layer of a lateritic podzolic (Yalanbee) and from a yellow earth (Merredin) at $30-60 \mathrm{~cm}$ depth. Some properties of the two soils are given in Table 1. All samples were air-dried and sieved through a $2 \mathrm{~mm}$ mesh sieve before use.

Table 1. Soil properties

\begin{tabular}{|c|c|c|}
\hline \multirow[t]{2}{*}{ Property } & \multicolumn{2}{|c|}{ Soil } \\
\hline & Yalanbee & Merredin \\
\hline Great soil group & lateritic-podzolic & yellow earth \\
\hline Organic matter $(\%)$ & $1 \cdot 06$ & 0.09 \\
\hline $\mathrm{pH}^{\mathrm{A}}$ & $5 \cdot 66$ & $4 \cdot 31$ \\
\hline Ionic strength & $1 \times 10^{-3}$ & $2 \cdot 4 \times 10^{-3}$ \\
\hline $\begin{array}{l}\text { Cation exchange } \\
\text { capacity }\left(\mathrm{Cg}^{-1}\right)\end{array}$ & $5 \cdot 8$ & $2 \cdot 9$ \\
\hline Buffer capacity ${ }^{B}$ & $1 \cdot 30$ & $1 \cdot 21$ \\
\hline $\begin{array}{l}\text { Gravimetric water } \\
\text { content at field capacity }\left(\mathrm{g} \mathrm{g}^{-1}\right)\end{array}$ & $0 \cdot 104$ & $0 \cdot 101$ \\
\hline $\begin{array}{l}\text { Gravimetric water } \\
\text { content when air dry }\left(\mathrm{g} \mathrm{g}^{-1}\right)\end{array}$ & 0.01 & 0.01 \\
\hline
\end{tabular}

A $1: 5$ soil : $0.002 \mathrm{M} \mathrm{CaCl}_{2}$ ratio.

${ }^{\mathrm{B}}$ Rate of change in $\mathrm{pH}$ per mmole of acid or base added to $100 \mathrm{~g}$ soil.

\section{Soil Incubation}

The two soils were incubated for 32 days at $30^{\circ} \mathrm{C}$ with four levels of added plant material at two soil water contents (air-dry and field capacity). The higher soil temperatures were used to speed up incubation times. At $30^{\circ} \mathrm{C}$, microbial activity is increased with a minimum of disturbance to the population composition and little change in the by-products produced by metabolic processes (Griffin 1972). The chemical reaction rates and microbial activity of the elevated temperature may be described by the Arrhenius equation (Castellan 1970), and so the conditions of incubation are equivalent to 90 days at $15^{\circ} \mathrm{C}$, i.e. the average soil temperature during winter in the regions where the soils were collected (Cotterill, personal communication).

Air-dried lucerne chaff (Medicago sativa), ground to pass through a $0.5 \mathrm{~mm}$ mesh sieve, was thoroughly mixed with $300 \mathrm{~g}$ subsamples of each soil at the rates of $0,2 \cdot 3,4 \cdot 4$ and $6 \cdot 5 \mathrm{~g} 100 \mathrm{~g}^{-1}$ for

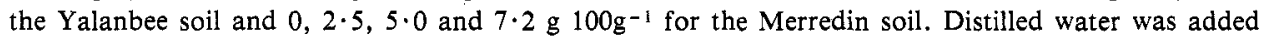
to bring the water content to the desired value. The mixture was placed in a $500 \mathrm{ml}$ plastic container, and plastic beads were placed on the top of the soil to reduce evaporation. Water was added to the field capacity treatments each day to keep them at field capacity. After incubation, the field capacity treatments were dried at $30^{\circ} \mathrm{C}$ and then all soil samples were stored at $4^{\circ} \mathrm{C}$ before analysis.

\section{Plant Analysis}

A nitric-perchloric acid digest was used to determine $\mathrm{Ca}, \mathrm{Mg}, \mathrm{Na}$ and $\mathrm{K}$ by AAS and $\mathrm{P}$ by the molybdovanadate method (Black 1965). N (Kjeldahl method), C (Walkley-Black method; Black 1965), ash content and ash alkalinity (Pierre and Banwart 1973) were also determined. A water soluble extract was prepared by shaking with deionized water at a ratio of $1: 10$ for $16 \mathrm{~h}$. The $\mathrm{pH}$ of the extract was noted and the solution potentiometrically titrated using the same method as Young et al. (1981). The end-point of the titration was taken as the region of the curve with the greatest slope (rather than an arbitrary $\mathrm{pH}$ ), and was considered to be the $\mathrm{pH}$ at which all the carboxyl groups were fully dissociated. 


\section{Soil Analysis}

The soils were analysed for organic matter (the Walkley-Black method; Black 1965), ionic strength at field capacity (Gillman and Bell 1978) and CEC (1 M NH 4 Cl; Black 1965).

$\mathrm{pH}$ was determined in $0.002 \mathrm{M} \mathrm{CaCl}_{2}$ (i.e. approximate ionic strength of West Australian soils; Dolling and Ritchie 1985) after shaking for $16 \mathrm{~h}$ at a soil-liquid ratio of 1:5. A Beckman $\phi 71 \mathrm{pH}$ meter with a combination electrode was used to measure the $\mathrm{pH}$ of the clear supernatant liquid after any $\mathrm{pH}$ drift was $<0.005 \mathrm{pH}$ units over a $30 \mathrm{~s}$ period.

The buffer capacity of each soil was determined before and after incubation for each treatment. The buffer capacity may be estimated from the slope of a curve of $\mathrm{pH}$ versus mmole of acid or alkali added per $100 \mathrm{~g}$ of soil. Eight points on the curve (in the $\mathrm{pH}$ range 3-7) were determined by adding known aliquots of $0.02 \mathrm{M}$ calcium hydroxide and $0.1 \mathrm{M} \mathrm{HCl}$ in $20 \mathrm{ml}$ of $0.002 \mathrm{M}$ calcium chloride to triplicate $4 \mathrm{~g}$ samples of each treatment. The samples were shaken for $16 \mathrm{~h}$ and the $\mathrm{pH}$ of the supernatant measured as described previously.

\section{Results}

\section{Properties of the Plant Material}

The plant material contained (\% oven dry): $48 \cdot 7 \mathrm{C}, 2 \cdot 94 \mathrm{~N}, 9 \cdot 6$ ash, $1.48 \mathrm{Ca}$, $0.28 \mathrm{Mg}, 0.34 \mathrm{Na}, 2.3 \mathrm{~K}$ and $0.29 \mathrm{P}$, and had an ash alkalinity of $88 \mathrm{mmole}$ $100 \mathrm{~g}^{-1}$. The $\mathrm{pH}$ of the deionized water $(5 \cdot 7)$ was unchanged by the extraction of the water-soluble component of the plant material. Potentiometric titration indicated that the acids present in the water soluble component were $50 \%$ dissociated at $\mathrm{pH} 4 \cdot 2$ (i.e. $\mathrm{pK}_{\mathrm{m}}=4 \cdot 2$ ) and $83 \%$ dissociated at $\mathrm{pH} 5 \cdot 7$.

\section{Soil Incubation with Plant Material}

At field capacity, the $\mathrm{pH}$ of both soils increased with small organic matter additions and then appeared to reach a maximum value with larger additions (Fig. 1). The decrease in the change in $\mathrm{pH}$ with increasing organic matter is due to the concurrent increase in the soil buffer capacity.

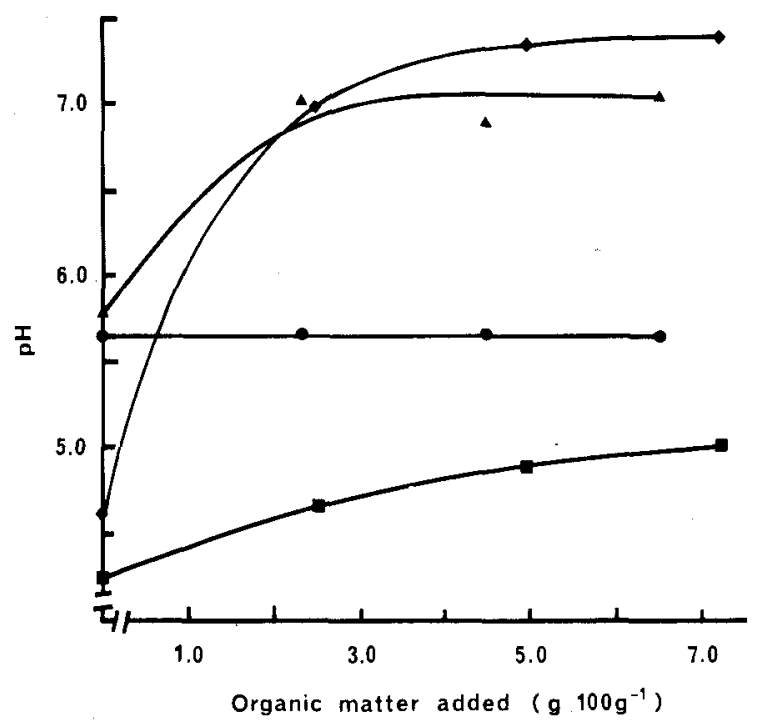

Fig. 1. Variation in soil $\mathrm{pH}$ with organic matter added to Yalanbee soil at field capacity $(\mathbf{A})$ and air dry (O) and to Merredin subsoil at field capacity $(\bullet)$ and air dry $(\square)$.

In the nil water treatment, there was no change in $\mathrm{pH}$ of the Yalanbee soil, whereas the Merredin soil showed only a small increase in $\mathrm{pH}$ with increasing additions of plant material. The variation in soil $\mathrm{pH}$ with mmole of acid or alkali 
added was essentially linear for all treatments (Fig. 2). Regression analysis indicated that there was no statistical improvement in the description of the curves by fitting more complex functions.
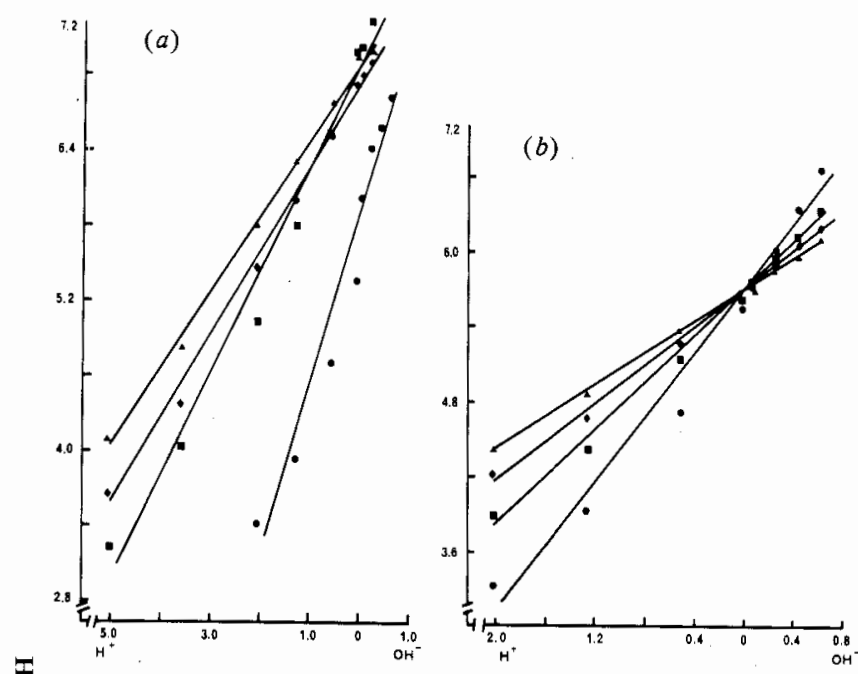

통

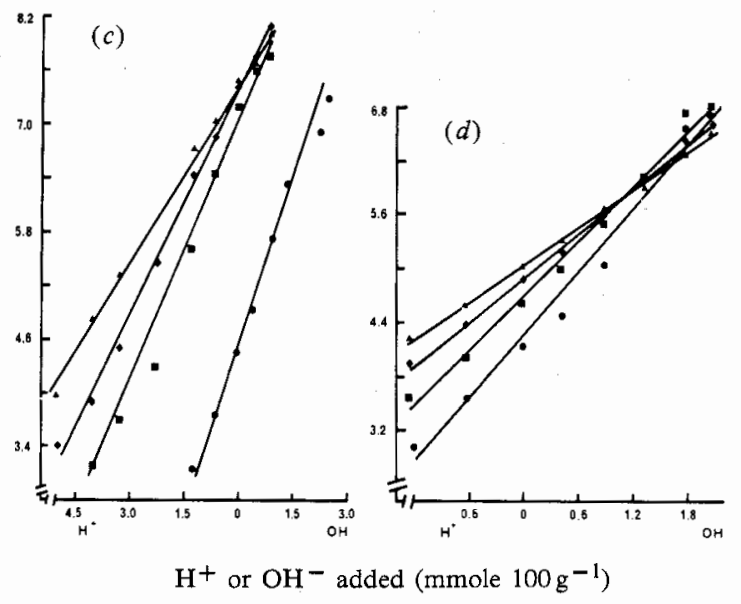

Fig. 2. Variation in soil pH with added acid or alkali (mmole $100 \mathrm{~g}^{-1}$ ) for Yalanbee at field capacity $(a)$ and air dry $(b)$ with $0(\mathbf{O}), 2 \cdot 3(\mathbf{a})$, $4 \cdot 4(\diamond)$ and $6 \cdot 5(\Delta) \mathrm{g} 100 \mathrm{~g}^{-1}$ organic matter added; Merredin at field capacity $(c)$ and air dry $(d)$ with $0(\bullet), 2 \cdot 5(\boldsymbol{D}), 5 \cdot 0(\downarrow)$ and $7 \cdot 2(\Delta)$ $\mathrm{g} 100 \mathrm{~g}^{-1}$ organic matter added.

As one might expect, the addition of plant material increased the buffer capacities of both soils, i.e. decreased the rate of change of $\mathrm{pH}$ per mmole of acid or base added to $100 \mathrm{~g}$ of soil (Fig. 2). Even though the soils did not differ markedly in their original buffer capacities, there was a slightly bigger increase in buffer capacity of the Yalanbee soil than for the Merredin soil at similar levels of organic matter addition. The water treatments did not have a significant effect on the buffer capacities of either soil. 


\section{Discussion}

The results reported here illustrate that the accumulation of organic matter does not necessarily cause soil acidification.

\section{Possible Mechanisms}

Organic matter is usually considered to lower soil $\mathrm{pH}$ by releasing hydrogen ions that were associated with organic anions or by nitrification in an open system (Porter et al. 1980). On the other hand, it may cause $\mathrm{pH}$ increases either by mineralization of organic anions to $\mathrm{CO}_{2}$ and water (thereby removing $\mathrm{H}^{+}$) or because of the 'alkaline' nature of the organic material (Helyar 1976). The 'alkaline' nature of plant material arises from the dissociation of organic acids (metabolized within the plant) in response to a cation/anion imbalance caused by $\mathrm{NH}_{4}{ }^{+}$uptake or $\mathrm{N}_{2}$ fixation. The plant reduces this imbalance by excreting $\mathrm{H}^{+}$ions and so the per cent dissociation of the organic acids (i.e. the anion concentration) within the plant increases (Israel and Jackson 1978).

No net change in soil $\mathrm{pH}$ will be observed if the anions released by the decaying plant material are in the vicinity of the $\mathrm{H}^{+}$ions. In some cases, however, the anions can become separated from the $\mathrm{H}^{+}$by being removed in a harvest or returned to the soil surface layers rather than to the subsoil where the majority of roots originally released the $\mathrm{H}^{+} . \mathrm{pH}$ changes would also be affected by subsequent plant growth and the type of $\mathrm{N}$ source available to the new crop.

The association of organic anions from the plant material with $\mathrm{H}^{+}$in the soil appears to be the more important process for $\mathrm{pH}$ changes in the systems studied here, i.e. the incorporation of imported plant material into a well-aerated soil in the absence of plant growth. The effects of mineralization (and other $\mathrm{H}^{+}$ consuming or $\mathrm{OH}^{-}$producing processes such as ammonia hydrolysis and nitrate reduction by microorganisms) would probably be counterbalanced by a concomitant increase in nitrification. Barrow (1960) also observed an increase in $\mathrm{pH}$ when soil was incubated with plant material, but attributed it to the inhibition of nitrification. In contrast to this study, however, it is not apparent that his soils were aerated during incubation.

\section{$H^{+}$Release by Organic Matter}

The release of $\mathrm{H}^{+}$ions by organic mater is dependent on the initial $\mathrm{pH}$ of the soil and the dissociation constants (pK) of the weak organic acids (Helyar 1976). For example, if the $\mathrm{pH}$ of the soil is less than the $\mathrm{pK}$ of the weak acid groups on added organic matter, there will be an increase in $\mathrm{pH}$ due to association of $\mathrm{H}^{+}$ from the soil with some of the organic anions. The acidic nature of the acid groups is usually characterized by determining a median $\mathrm{pK}$ at $50 \%$ dissociation, the $\mathrm{pK}_{\mathrm{m}}$ or $\mathrm{pK}_{\mathrm{a}}$ (Young et al. 1981; Stevenson 1982). However, if the organic acids are more than $50 \%$ dissociated and they are added to a soil with initial $\mathrm{pH}<\mathrm{pK}_{\mathrm{m}}$, the magnitude of the expected $\mathrm{pH}$ change would be greater. If the soil $\mathrm{pH} \approx \mathrm{pK}_{\mathrm{m}}$, the $\mathrm{pH}$ would rise rather than remain constant, and for soil $\mathrm{pH}>\mathrm{pK}_{\mathrm{m}}$, the $\mathrm{pH}$ drop observed would be smaller than expected. Therefore, the actual per cent dissociation of organic acids (i.e. anion concentration) as they are released into the soil would be a better indicator of their ability to acidify a soil than their $\mathrm{pK}_{\mathrm{m}}$. 


\section{pH Changes in Air-dry Soils}

The initial $\mathrm{pH}$ of the Merredin subsoil was approximately equal to the $\mathrm{pK}_{\mathrm{m}}$ of the water soluble component of the added lucerne hay. However, the potentiometric properties of the plant material indicated that the organic acids were $\sim 80 \%$ dissociated when released into the soil. Consequently, the soil $\mathrm{pH}$ rose as $\mathrm{H}^{+}$ions were removed from solution by those weak acid sites which would normally be associated at the initial soil $\mathrm{pH}$. The magnitude of the change would be modified by the buffering power of the soil and the organic material itself.

The initial $\mathrm{pH}$ of the Yalanbee soil was greater than the $\mathrm{pK}_{\mathrm{m}}$ of the soluble organic acids, and so one might have expected the $\mathrm{pH}$ to fall if the acids were $50 \%$ dissociated. In fact, there was no change in the $\mathrm{pH}$ of the soils upon incubation with plant material because the $\mathrm{pH}$ of the water extract of the plant material was approximately the same as the initial soil $\mathrm{pH}$, and there was very little disturbance of the dissociation of the organic acids.

\section{The Effect of Water Treatments on $\mathrm{pH}$ Changes}

For both soils, the $\mathrm{pH}$ changes were greater at field capacity than in the air-dry water treatments. In contrast, the buffer capacity was essentially independent of the water treatments imposed. This could be because the method of measurement does not distinguish between buffering properties of the soil surfaces and the soil solution, whereas $\mathrm{pH}$ is a soil solution property only. Therefore, it would appear that the water soluble component of the organic material plays a major role in the $\mathrm{pH}$ changes.

There would be little microbial activity during the incubation of the nil water treatments due to the lack of water (Gray 1976). Therefore, the results obtained for the air-dry treatments would be approximately similar to those obtained at field capacity but with no incubation period. This is because equilibration of the weak acid groups on the plant material would occur during the $\mathrm{pH}$ measurement step of shaking the soil with $\mathrm{CaCl}_{2}$ for $17 \mathrm{~h}$. Consequently, the difference in $\mathrm{pH}$ between the two water treatments must be due to changes in the organic material that have occurred during incubation.

The changes in organic material with time could be explained either by microbial activity removing $\mathrm{H}^{+}$ions by breaking down the organic anions to $\mathrm{CO}_{2}$ and water, further dissolution of organic anions or by reactions with soil surfaces. Parfitt $e t$ al. (1977) have shown that dissociated carboxyl anions of humic and fulvic acids can displace hydroxyl groups from goethite surfaces. As already discussed, the net effect on $\mathrm{pH}$ of microbial activity in our systems is probably negligible. Also, if mineralization was a major cause of the difference in $\mathrm{pH}$ increases between water treatments, then one would expect to observe a decrease in buffer capacity with time because of the removal of organic buffering materials by microbial breakdown.

The greater $\mathrm{pH}$ changes in the field capacity water treatments could be explained by release of more organic anions as time progresses or by their adsorption on soil surfaces.

Further release of organic anions could be a possible explanation for the difference in $\mathrm{pH}$ changes between water treatments for the Merredin soil but not for the Yalanbee soil. In the latter case, adsorption onto soil surfaces could have contributed to the $\mathrm{pH}$ increase observed. However, the rise is equivalent to a very small consumption of $\mathrm{H}^{+}$ions, which is 17 times less than the $\mathrm{pH}$ change for the Merredin soil under the same conditions. 
Hoyt and Turner (1975) also observed a variation in $\mathrm{pH}$ with time when different organic materials were mixed with soil. Initially, the soil pH rose, but after 24 weeks' incubation the $\mathrm{pH}$ had nearly returned to its original value before adding organic matter. Direct comparisons with this work are not possible because they were studying an open system from which a crop of barley was harvested. However, the same trend may have been observed if longer time periods had been used.

The temporary nature of the $\mathrm{pH}$ changes discussed above illustrates the difficulties of monitoring $\mathrm{pH}$ changes in the field. It also indicates that as well as long-term changes in $\mathrm{pH}$ there are also short-term variations that do not necessarily reflect the overall long-term changes but may have a marked effect on plant growth.

\section{Conclusions}

Decaying plant material is less likely to contribute to soil acidification when it has a high anion concentration, and its effect on $\mathrm{pH}$ may vary quite widely from one soil to another and between different agricultural practices (e.g. grazing pastures versus hay production). The importance of $\mathrm{H}^{+}$release by organic matter may have been overestimated as a mechanism of soil acidification because the $\mathrm{pK}_{\mathrm{m}}$ rather than the anion concentration of the organic material has been used as an indicator of the ability of organic materials to acidify soils.

\section{Acknowledgments}

We would like to thank Professor A. D. Robson and Dr W. M. Porter for helpful discussions on the work, and Mrs J. Norris for technical assistance.

\section{References}

Barrow, N. J. (1960). Stimulated decomposition of soil organic matter during the decomposition of added organic materials. Aust. J. Agric. Res. 11, 331-8.

Black, C. A. (1965). 'Methods of Soil Analysis. Part 2.' (American Society of Agronomy: Madison, Wis.)

Castellan, G. W. (1970). 'Physical Chemistry.' (Addison-Wesley: Massachusetts.)

Dolling, P. J., and Ritchie, G. S. P. (1985). Estimates of soil solution ionic strength and the determination of $\mathrm{pH}$ in West Australian soils. Aust. J. Soil Res. 23, 309-14.

Gillman, G. P., and Bell, L. C. (1978). Solution studies on weathered soils from tropical North Queensland. Aust. J. Soil Res. 16, 67-77.

Gray, T. R. G. (1976). Survival of vegetative microbes in soil. In 'The Survival of Vegetative Microbes'. (Ed. T. R. G. Gray and J. R. Postgate.) pp. 327-64. (University Press: Cambridge.)

Griffin, D. M. (1972). 'Ecology of Soil Fungi.' p. 144. (Syracuse University Press: New York.)

Helyar, K. R. (1976). Nitrogen cycling and soil acidification. J. Aust. Inst. Agric. Sci. 42, 217-21.

Hoyt, P. B., and Turner, R. C. (1975). Effects of organic materials added to very acid soils on $\mathrm{pH}$, aluminium, exchangeable $\mathrm{NH}_{4}$, and crop yields. Soil Sci. 119, 227-37.

Israel, D. W., and Jackson, W. A. (1978). The influence of nitrogen nutrition on ion uptake and translocation by leguminous plants. In 'Mineral Nutrition of Legumes in Tropical and Subtropical Soils'. (Eds C. S. Andrew and E. J. Kamprath.) pp. 113-26. (CSIRO Aust.: Melbourne.)

Jarvis, S. C., and Robson, A. D. (1983). The effect of nitrogen nutrition of plants on the development of acidity in Western Australian soils. I. Effects with subterranean clover grown under leaching conditions. Aust. J. Agric. Res. 34, 345-53.

Pierre, W. H., and Banwart, W. L. (1973). The excess-base and excess-base/nitrogen ratio of various crop species and of plant parts. Agron. J. 64, 91-6.

Porter, W. M., Cox, W. J., and Wilson, I. (1980). Soil acidity . . . is it a problem in Western Australia? West Aust. J. Agric. 21, 126-33.

Riley, D., and Barber, S. A. (1969). Bicarbonate accumulation and pH changes at the soybean (Glycine $\max (\mathrm{L})$ Merr.) root-soil interface. Soil Sci. Soc. Am. Proc. 33, 905-8. 
Russell, J. S. (1960). Soil fertility changes in the long-term experimental plots at Kybybolite, South Australia. I. Changes in pH, total nitrogen, organic carbon, and bulk density. Aust. J. Agric. Res. 11, 902-26.

Stevenson, F. J. (1982). 'Humus Chemistry.' (Wiley Interscience: New York.)

Williams, C. H. (1980). Soil acidification under clover pasture. Aust. J. Exp. Agric. Anim. Husb. 20, 561-7.

Williams, C. H., and Donald, C. M. (1957). Changes in organic matter and $\mathrm{pH}$ in a podzolic soil as influenced by subterranean clover and superphosphate. Aust. J. Agric. Res. 8, 179-89.

Young, S. D., Bache, B. W., Welch, D., and Anderson, H. A. (1981). Analysis of the potentiometric titration of natural and synthetic polycarboxylates. J. Soil Sci. 32, 579-92. 